\title{
Reclassification of Thermoanaerobium acetigenum as Caldicellulosiruptor acetigenus comb. nov. and emendation of the genus description
}

\author{
Rob U. Onyenwoke, ${ }^{1}$ Yong-Jin Lee, ${ }^{1}$ Slawomir Dabrowski, ${ }^{2}$ \\ Birgitte K. Ahring ${ }^{2}$ and Juergen Wiegel ${ }^{1}$ \\ ${ }^{1}$ Department of Microbiology, University of Georgia, Athens, GA 30602-2605, USA \\ ${ }^{2}$ Department of Environmental Science and Engineering, Technical University of Denmark, \\ 2800 Lyngby, Denmark
}

Correspondence

Juergen Wiegel

jwiegel@uga.edu

\begin{abstract}
Although the type species of the genus Thermoanaerobium, Thermoanaerobium brockii, was transferred to Thermoanaerobacter, Thermoanaerobium acetigenum was not transferred. Therefore, Thermoanaerobium acetigenum should be reclassified. Based on 16S rRNA gene sequence analysis and re-examination of physiological properties of the type strain, $\mathrm{X} 6 \mathrm{~B}^{\mathrm{T}}$ $\left(=\mathrm{DSM} 7040^{\top}=\right.$ ATCC BAA $-1149^{\top}$ ), we propose that Thermoanaerobium acetigenum should be reclassified as Caldicellulosiruptor acetigenus comb. nov. Strain $\mathrm{X}^{6} \mathrm{~B}^{\top}$ contains two separate 16S rRNA genes bracketing another species in the phylogenetic 16S rRNA gene-based tree.
\end{abstract}

Thermoanaerobium acetigenum strain $\mathrm{X} 6 \mathrm{~B}^{\mathrm{T}}$, an anaerobic, thermophilic bacterium, was isolated by Nielsen et al. (1993) using xylan as the substrate. This bacterium, a Gramtype positive (Wiegel, 1981), low-G $+\mathrm{C}$ content rod, has many characteristics of a typical member of the Firmicutes (Gibbons \& Murray, 1978). Based on its physiological properties alone, it was placed in the genus Thermoanaerobium, the type species of which is Thermoanaerobium brockii (Zeikus et al., 1979).

Because the 16S rRNA gene sequence for Thermoanaerobium acetigenum $\mathrm{X} 6 \mathrm{~B}^{\mathrm{T}}$ had not been determined previously, the classification of Thermoanaerobium acetigenum $\mathrm{X}_{6 \mathrm{~B}} \mathrm{~B}^{\mathrm{T}}$ was therefore based only on some physiological similarities. Although the type species of Thermoanaerobium, Thermoanaerobium brockii, was reclassified as Thermoanaerobacter brockii by Lee et al. (1993) and, subsequently, as Thermoanaerobacter brockii subsp. brockii (type strain $\mathrm{HTD}^{\mathrm{T}}$ ) by Cayol et al. (1995), Thermoanaerobium acetigenum $\mathrm{X} 6 \mathrm{~B}^{\mathrm{T}}$ was not transferred to the genus Thermoanaerobacter (Wiegel \& Ljungdahl, 1981) because of the lack of $16 \mathrm{~S}$ rRNA gene sequence analysis. Here we report on the assignment of the type strain of Thermoanaerobium acetigenum to the genus Caldicellulosiruptor as Caldicellulosiruptor acetigenus comb. nov., based on 16S rRNA gene sequence, DNADNA hybridization analysis and retesting of its properties. Special attention was given to cellulose degradation, as all other presently known Caldicellulosiruptor species are cellulolytic, whereas strain $\mathrm{X} 6 \mathrm{~B}^{\mathrm{T}}$ has been described as being non-cellulolytic.

The GenBank/EMBL/DDBJ accession numbers for the 16S rRNA gene sequences of strain DSM $7040^{\top}$ are AY772476 and AY772477.
Strain $\mathrm{X} 6 \mathrm{~B}^{\mathrm{T}}$ was obtained as a freeze-dried culture of strain DSM $7040^{\mathrm{T}}$ from the DSMZ (Braunschweig, Germany). To determine the 16S rRNA gene sequence, Thermoanaerobium acetigenum DSM $7040^{\mathrm{T}}$ was grown under anaerobic conditions (Ljungdahl \& Wiegel, 1986; Angelidaki et al., 1990). A basal salts medium (final $\mathrm{pH} 7 \cdot 3-7 \cdot 4$ ) was prepared as described by Nielsen et al. (1993). Strain DSM $7040^{T}$ was grown in basal salts medium supplemented with yeast extract $(0.3 \%)$, tryptone $(1 \cdot 0 \%)$ and glucose $(0.5 \%)$, and subjected to two rounds of isolation of single colonies using yeast extract, tryptone, glucose salts medium solidified with $2 \cdot 2 \%$ Gelrite (colonies became visible after incubation at $65^{\circ} \mathrm{C}$ for $48-72 \mathrm{~h}$ ). Because the initial 16S rRNA gene sequence analysis yielded two different $16 \mathrm{~S}$ rRNA species, which bracketed another Caldicellulosiruptor species, it became necessary to confirm the purity of the culture further. Therefore, strain DSM $7040^{\mathrm{T}}$ was grown using three different media (substrate conditions as described below), and each culture was then subjected to three subsequent rounds of single-cell colony isolation. To establish three lines of cultures, strain DSM $7040^{\mathrm{T}}$ was grown in the abovedescribed basal salts medium, supplemented with yeast extract, tryptone, glucose and brain heart infusion $(0 \cdot 2 \%)$ (termed BYTG medium). From this culture, three parallel cultures were inoculated $(0 \cdot 1 \%$ inoculum) using the following media: (i) basal salts plus $0 \cdot 2 \%$ arabinose medium, (ii) basal salts plus $0 \cdot 2 \%$ raffinose medium and (iii) BYTG medium. Arabinose- and raffinose-supplemented basal salts media were used because the closest Caldicellulosiruptor species to strain $\mathrm{X} 6 \mathrm{~B}^{\mathrm{T}}$ on the phylogenetic tree (Fig. 1) are unable to use these substrates (Table 1). After checking microscopically that the cultures were suspensions of individual cells and did not contain any clumps or associations 


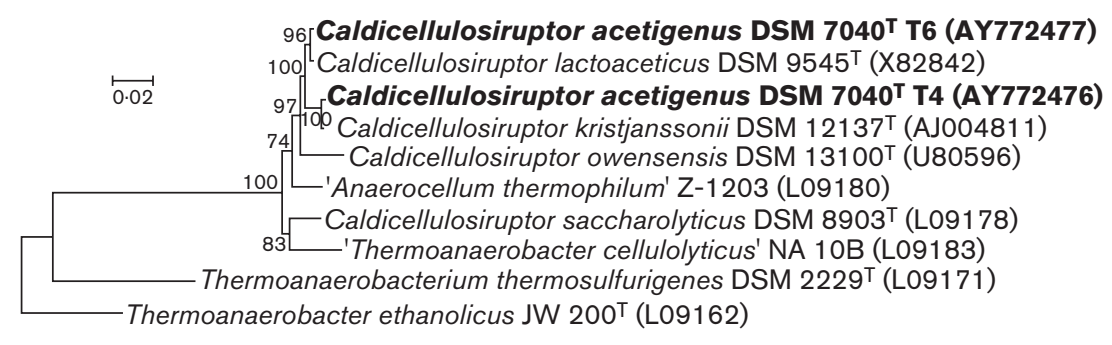

Fig. 1. Neighbour-joining tree showing the estimated phylogenetic relationships of Caldicellulosiruptor acetigenus $\mathrm{X} \mathrm{B}^{\mathrm{T}}$ based on 16S rRNA gene sequence data with maximum-likelihood correction for synonymous changes. The $16 \mathrm{~S}$ rRNA gene data used represent Escherichia coli DSM $30083^{\top}$ nucleotide positions 42-1424. Numbers at nodes indicate bootstrap support percentages for 1000 replicates. Bar, 0.02 nucleotide substitutions per site. GenBank accession numbers are given in parentheses. of cells, each of the above cultures was used to inoculate dilution series of Gelrite shake-roll tubes (Ljungdahl \& Wiegel, 1986), with $2 \cdot 2 \%(\mathrm{w} / \mathrm{v})$ Gelrite, to obtain single-cell colonies. The Gelrite shake-roll tubes were incubated at $65^{\circ} \mathrm{C}$ for $48-72 \mathrm{~h}$ before colonies became visible. Colonies were picked in an anaerobic chamber (Coy Products) and resuspended in a tube containing $0 \cdot 3-0 \cdot 4 \mathrm{ml}$ of the corresponding medium, which was then used to inoculate the next round of Gelrite shake-roll tubes. This process of colony picking was repeated for three rounds of colony isolation with three colonies being picked from each of the arabinose, raffinose and BYTG media after the third and final round. Each of the picked final colonies was reinoculated into a fresh tube of the medium from which it was isolated, resulting in nine cultures: three with the arabinose medium, three with the raffinose medium and three with BYTG medium.

Subsequent extraction of DNA from the nine cultures was performed using a DNeasy Tissue kit (Qiagen). The DNA was then amplified using a bacterial domain-specific primer set for 16S rRNA, 27 forward and 1492 reverse (Lane, 1991). PCR was carried out as described previously (Lee et al., 2005). The PCR products were purified using a QIAquick PCR Purification kit (Qiagen) and sequenced by Macrogen (Seoul, Korea). PCR products from the colonies were cloned

Table 1. Differential characteristics of Caldicellulosiruptor acetigenus $\mathrm{X}^{6} \mathrm{~B}^{\top}$, Caldicellulosiruptor kristjanssonii $177 \mathrm{R}^{\mathrm{B}} \mathrm{B}^{\mathrm{T}}$ and Caldicellulosiruptor lactoaceticus $6 \mathrm{~A}^{\mathrm{T}}$

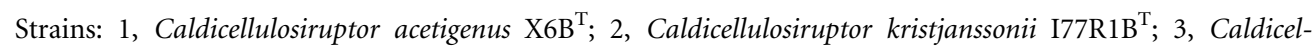
lulosiruptor lactoaceticus $6 \mathrm{~A}^{\mathrm{T}}$.

\begin{tabular}{|c|c|c|c|}
\hline Characteristic & 1 & 2 & 3 \\
\hline Temperature range for growth (optimum) $\left({ }^{\circ} \mathrm{C}\right)^{*}$ & $50-78(65-68)^{a}$ & $50-82(78)^{b}$ & $50-78(68)^{b}$ \\
\hline $\mathrm{pH}$ range for growth (optimum) $\dagger$ & $5 \cdot 2-8 \cdot 5(7 \cdot 0)^{a}$ & $5 \cdot 8-8 \cdot 0(7 \cdot 0)^{b}$ & $5 \cdot 8-8 \cdot 2(7 \cdot 0)^{b}$ \\
\hline \multicolumn{4}{|l|}{ Substrate utilization $\neq:$} \\
\hline Arabinose & + & - & - \\
\hline Fructose & + & + & - \\
\hline D-Galactose & + & + & - \\
\hline D-Glucose & + & + & - \\
\hline Mannose & + & + & - \\
\hline Raffinose & + & - & - \\
\hline Sucrose & + & + & - \\
\hline Trehalose & + & + & - \\
\hline Avicel & - & + & + \\
\hline \multicolumn{4}{|l|}{ Growth inhibition: } \\
\hline $\mathrm{H}_{2}(0 \cdot 5 \mathrm{~atm})$ & + & - & - \\
\hline $\mathrm{NaCl} \S$ & + & - & - \\
\hline Lactate as a major fermentation product & - & + & + \\
\hline
\end{tabular}

${ }^{\star}$ Determined at: $a, \mathrm{pH} 7 \cdot 0$ with xylose as substrate; $b, \mathrm{pH} 7 \cdot 0$ with cellobiose as substrate.

$\dagger$ Determined at: $a, 68^{\circ} \mathrm{C}$ with xylose; $b, 70^{\circ} \mathrm{C}$ with cellobiose.

$\ddagger$ Substrate concentrations were $2 \cdot 0 \mathrm{~g} \mathrm{l}^{-1}$.

$\S \mathrm{NaCl}$ concentrations tested were $0 \cdot 2 \%$ for strains $\mathrm{X} 6 \mathrm{~B}^{\mathrm{T}}$ and $\mathrm{I} 77 \mathrm{R} 1 \mathrm{~B}^{\mathrm{T}}$ and $0.5 \%$ for strain $6 \mathrm{~A}^{\mathrm{T}}$. 
using a TOPO TA Cloning kit (Invitrogen). Clones were randomly chosen, from which plasmid DNA was extracted by using an Eppendorf FastPlasmid Mini kit (Brinkman). The DNA was subsequently amplified, purified and sequenced. The sequence similarities were determined using Sequencher v4.1.4 (Gene Codes). Ten clones were sequenced, resulting in two similar sets of sequences (Fig. 1; termed T6 and T4, GenBank accession nos AY772477 and AY772476, respectively). Three clones with the same 16S rRNA gene sequence were never obtained from a single culture, suggesting that an even distribution of clones with the different sequences existed. Analysis of the $16 \mathrm{~S}$ rRNA gene sequence using nucleotide to nucleotide BLAST (BLASTN) at NCBI (http://www.ncbi.nlm.nih.gov/blast/) to retrieve the most significant homologues of the query $16 \mathrm{~S}$ rRNA gene sequence revealed that the most significant sequence alignments of Thermoanaerobium acetigenum $\mathrm{X} 6 \mathrm{~B}^{\mathrm{T}}$ were with Caldicellulosiruptor species (Sissons et al., 1987; Rainey et al., 1994), with Caldicellulosiruptor lactoaceticus 6A ${ }^{\mathrm{T}}$ (Mladenovska et al., 1995) and Caldicellulosiruptor kristjanssonii I77R1B ${ }^{\mathrm{T}}$ (Bredholt et al., 1999) as the closest relatives (Fig. 1). Subsequently, 16S rRNA gene sequencebased phylogenetic trees were generated using CLUSTAL_X (Thompson et al., 1997) for sequence alignments, and phylogeny inference package (PHYLIP) software (Felsenstein, 1989) and neighbour-joining algorithms (Saitou \& Nei, 1987) to look at differing tree constructions and to generate distance matrices. TreeExplorer (Kumar et al., 1994), a supplemental program of MEGA, was used to view the tree. The phylogenetic trees generated (the neighbour-joining tree is shown in Fig. 1) showed clearly that Thermoanaerobium acetigenum $\mathrm{X} \mathrm{B}^{\mathrm{T}}$ belongs to the clade of Caldicellulosiruptor and not to the genus Thermoanaerobacter or Thermoanaerobacterium. Each of the repurified strains exhibited the two different $16 \mathrm{~S}$ rRNA sequences. In contrast to other reported cases, e.g. Clostridium paradoxum (Rainey et al., 1996), the two sequences were not juxtaposed, but rather separated by a sequence of another species, Caldicellulosiruptor kristjanssonii. A comparable situation has been reported by Amann et al. (2000), i.e. single-cell-derived pure cultures contained two different $16 \mathrm{~S}$ rRNA genes with about $5 \%$ inferred difference in substitutions and bracketing a different species. The relative distance between the two identified Thermoanaerobium acetigenum $\mathrm{X} 6 \mathrm{~B}^{\mathrm{T}} 16 \mathrm{~S}$ rRNA gene sequences was about $2 \%$ and the distance to the closest neighbours Caldicellulosiruptor lactoaceticus $6 \mathrm{~A}^{\mathrm{T}}$ and Caldicellulosiruptor kristjanssonii $\mathrm{I} 77 \mathrm{R}_{1} \mathrm{~B}^{\mathrm{T}}$ was around $1 \%$. Therefore, DNA-DNA hybridization experiments were performed using the method described by De Ley et al. (1970) and modified by Huß et al. (1983). Chromosomal DNA for DNA-DNA hybridization was extracted and purified using a Maxi Genomic ${ }_{[0]}$ DNA Prep kit (A\&A Biotechnology).

DNA-DNA hybridization values between Thermoanaerobium acetigenum DSM $7040^{\mathrm{T}}$ and Caldicellulosiruptor owensensis $\mathrm{OL}^{\mathrm{T}}$, Caldicellulosiruptor lactoaceticus $6 \mathrm{~A}^{\mathrm{T}}$ and Caldicellulosiruptor kristjanssonii $\mathrm{I}_{77 \mathrm{R} 1 \mathrm{~B}^{\mathrm{T}}}$ were $34 \cdot 3,50 \cdot 9$ and $53 \cdot 1 \%$, respectively. These values are all significantly below the $70 \%$ relatedness mark that would indicate a relationship at the species level (Wayne et al., 1987) and clearly distinguish Thermoanaerobium acetigenum $\mathrm{X}_{6} \mathrm{~B}^{\mathrm{T}}$ from these three Caldicellulosiruptor species that are its closest neighbours in the $16 \mathrm{~S}$ rRNA gene-based phylogenetic tree (Fig. 1). The repeated isolation of single-cell colonies after growth in different media, the observed homogeneity of the colony and cell morphologies with and among cultures (using microscopy) and the fact that all isolated colonies gave rise to the two different $16 \mathrm{~S}$ rRNA sequences indicate that it is unlikely that the two sequences are due to a mixed culture having been analysed. These results indicate that Thermoanaerobium acetigenum $\mathrm{X} 6 \mathrm{~B}^{\mathrm{T}}$ belongs in the genus Caldicellulosiruptor, a member of the order Clostridiales, and not in the genus Thermoanaerobacter, order 'Thermoanaerobacteriales' (Garrity et al., 2002).

Members of the genus Caldicellulosiruptor have the characteristic trait of coupling cellulose degradation to growth (Rainey et al., 1994). However, Thermoanaerobium acetigenum $\mathrm{X}_{6} \mathrm{~B}^{\mathrm{T}}$ was characterized previously (Nielsen et al., 1993) as being incapable of cellulose degradation.

Thermoanaerobium acetigenum DSM $7040^{\mathrm{T}}$ was retested for the ability to degrade cellulose using Whatman no. 1 filter paper and carboxymethylcellulose $(1.0 \% \mathrm{w} / \mathrm{v}, \mathrm{CMC} 7 \mathrm{LT}$ or 7M; Hercules). In addition, cellulase activity was determined by the use of the reducing sugar assay employing p-hydroxybenzoic acid hydrazide and glucose as a standard (Lever, 1973). Thermoanaerobium acetigenum DSM $7040^{\mathrm{T}}$ was incapable of degrading Whatman no. 1 filter cellulose with or without $0.05 \%(\mathrm{w} / \mathrm{v})$ yeast extract, but utilized $\mathrm{CMC}$, exhibiting moderate growth with $1.0 \%$ of the low substitution (substitution level $0 \cdot 7$ of 3 ) form Hercules 7LT or $7 \mathrm{M}$. Eleven and $10 \mu \mathrm{mol} \mathrm{ml}{ }^{-1}$, respectively, of reduced sugar residues was released from the cultures after 4 days of incubation, with a requirement for yeast extract $(0 \cdot 05 \%$, w/v) for growth. Growth was not observed with only CMC 7LT/7M present. More highly substituted (e.g. 1·2 out of 3) CMCs (Hercules 12M or 12L) did not serve as substrates.

The substrate utilization spectrum of Thermoanaerobium acetigenum DSM $7040^{\mathrm{T}}$, as performed by Nielsen et al. (1993), was re-examined by adding various carbohydrates (to a final concentration of $2 \mathrm{~g} \mathrm{l}^{-1}$ ) from autoclaved stock solutions (pyruvate was filter-sterilized) to the basal media. Cultures were incubated at $73{ }^{\circ} \mathrm{C}$ for $48-72 \mathrm{~h}$. Growth of cultures with insoluble substrates was determined by cell counts (Olympus model Vanox microscope with a PetroffHausser counting chamber). The results confirmed the previously published data.

The 16S rRNA gene sequence analysis, CMC-cellulase activity and growth observed on low-substituted CMC indicate that Thermoanaerobium acetigenum belongs to the genus Caldicellulosiruptor, and we propose the name Caldicellulosiruptor acetigenus comb. nov. 


\section{Emended description of the genus Caldicellulosiruptor Rainey et al. 1995}

The description is the same as that given by Rainey et al. (1994) with the addition that some members do not possess the capacity to degrade crystalline cellulose or filter paper and cannot use cellulose as a carbon and energy source, but can hydrolyse CMC.

\section{Description of Caldicellulosiruptor acetigenus comb. nov.}

Caldicellulosiruptor acetigenus (a.ce.ti.ge' nus. L. n. acetum vinegar; L. v. genere, gignere to produce; N.L. masc. adj. acetigenus vinegar- or acetic acid-producing).

Basonym: Thermoanaerobium acetigenum Nielsen et al. 1994.

The description is based mainly on that given by Nielsen et al. (1993). Cells stain Gram-negative but have a Gramtype positive cell wall structure, occur singly or in pairs, and are about $3 \cdot 6-5 \cdot 9$ by $0 \cdot 7-1 \cdot 0 \mu \mathrm{m}$ in size. Sometimes occur as chains of up to eight cells. On solidified xylan-containing medium, off-white, milky-coloured colonies are observed. Strictly anaerobic chemoorganoheterotroph. At $\mathrm{pH} 7 \cdot 0$, growth occurs between 50 and $78^{\circ} \mathrm{C}$ (optimum $65-68^{\circ} \mathrm{C}$ ). Growth occurs at $\mathrm{pH} 5 \cdot 2-8 \cdot 6$ (optimum $7 \cdot 0$ ). Doubling time under optimal conditions is approximately $4 \mathrm{~h}$. Arabinose, cellobiose, fructose, D-galactose, D-glucose, lactose, maltose, mannose, raffinose, soluble starch, sucrose, trehalose, D-xylose and xylan support growth. Growth and CMC-cellulase activity is observed when grown on carboxymethylcellulose (Hercules CMC, 7LT or 7M) in the presence of traces of yeast extract, but not with filter paper or crystalline (Avicel) cellulose. Acetate, $\mathrm{CO}_{2}, \mathrm{H}_{2}$, ethanol and traces of isobutyric acid (but not lactate) are formed during growth with glucose or D-xylose. The DNA G+C content of the type strain is $35 \cdot 7 \pm 0.8 \mathrm{~mol} \%$ (chromatographic method).

The type strain is $\mathrm{X} 6 \mathrm{~B}^{\mathrm{T}}\left(=\mathrm{DSM} 7040^{\mathrm{T}}=\mathrm{ATCC}\right.$ BAA$1149^{\mathrm{T}}$ ), which was isolated from a combined biomat and sediment sample taken from a slightly alkaline hot spring at Hverðagerdi, Iceland.

\section{References}

Amann, G., Stetter, K. O., Llobet-Brossa, E., Amann, R. \& Anton, J. (2000). Direct proof for the presence and expression of two $5 \%$ different $16 \mathrm{~S}$ rRNA genes in individual cells of Haloarcula marismortui. Extremophiles 4, 373-376.

Angelidaki, I., Petersen, S. P. \& Ahring, B. K. (1990). Effects of lipids on thermophilic anaerobic digestion and reduction of lipid inhibition upon addition of bentonite. Appl Microbiol Biotechnol 33, 469-472.

Bredholt, S., Sonne-Hansen, J., Nielsen, P., Mathrani, I. M. \& Ahring, B. K. (1999). Caldicellulosiruptor kristjanssonii sp. nov., a cellulolytic, extremely thermophilic, anaerobic bacterium. Int J Syst Bacteriol 49, 991-996.
Cayol, J.-L., Ollivier, B., Patel, B. K. C., Ravot, G., Magot, M., Ageron, E., Grimont, P. A. D. \& Garcia, J.-L. (1995). Description of Thermoanaerobacter brockii subsp. lactiethylicus subsp. nov., isolated from a deep subsurface French oil well, a proposal to reclassify Thermoanaerobacter finnii as Thermoanaerobacter brockii subsp. finnii comb. nov., and an emended description of Thermoanaerobacter brockii. Int J Syst Bacteriol 45, 783-789.

De Ley, J., Cattoir, H. \& Reynaerts, A. (1970). The quantitative measurement of DNA hybridization from renaturation rates. Eur J Biochem 12, 133-142.

Felsenstein, J. (1989). PHYLIP - Phylogeny inference package (version 3.2). Cladistics 5, 164-166.

Garrity, G. M., Johnson, K. L., Bell, J. \& Searles, D. B. (2002). Taxonomic outline of the Procaryotes. In Bergey's Manual of Systematic Bacteriology, 2nd edn, release 3.0, pp. 1-366. New York: Springer. doi:10.1007/bergeysoutline200210

Gibbons, N. E. \& Murray, R. G. E. (1978). Proposals concerning the higher taxa of bacteria. Int J Syst Bacteriol 28, 1-6.

Huß, V. A. R., Festl, H. \& Schleifer, K. H. (1983). Studies on the spectrophotometric determination of DNA hybridization from renaturation rates. Syst Appl Microbiol 4, 184-192.

Kumar, S., Tamura, K. \& Nei, M. (1994). MEGA: molecular evolutionary genetics analysis software for microcomputers. Comput Appl Biosci 10, 189-191.

Lane, D. J. (1991). 16S/23S rRNA sequencing. In Nucleic Acid Techniques in Bacterial Systematics, pp. 115-175. Edited by E. Stackebrandt \& M. Goodfellow. Chichester: Wiley.

Lee, Y.-E., Jain, M. K., Lee, C., Lowe, S. E. \& Zeikus, J. G. (1993). Taxonomic distinction of saccharolytic thermophilic anaerobes: description of Thermoanaerobacterium xylanolyticum gen. nov., sp. nov., and Thermoanaerobacterium saccharolyticum gen. nov., sp. nov.; reclassification of Thermoanaerobium brockii, Clostridium thermosulfurogenes, and Clostridium thermohydrosulfuricum E100-69 as Thermoanaerobacter brockii comb. nov., Thermoanaerobacterium thermosulfurigenes comb. nov., and Thermoanaerobacter thermohydrosulfuricus comb. nov., respectively; and transfer of Clostridium thermohydrosulfuricum 39E to Thermoanaerobacter ethanolicus. Int J Syst Bacteriol 43, 41-51.

Lee, Y. J., Wagner, I. D., Brice, M. E., Kevbrin, V. V., Mills, G. L., Romanek, C. S. \& Wiegel, J. (2005). Thermosediminibacter oceani gen. nov., sp. nov. and Thermosediminibacter litoriperuensis sp. nov., new anaerobic thermophilic bacteria isolated from Peru Margin. Extremophiles 9, 375-383.

Lever, M. (1973). Colorimetric and fluorometric carbohydrate determination with $p$-hydroxybenzoic acid hydrazide. Biochem Med 7, 274-281.

Ljungdahl, L. G. \& Wiegel, J. (1986). Anaerobic fermentations. In Manual of Industrial Microbiology and Biotechnology, pp. 84-96. Edited by A. L. Demain \& N. A. Solomon. Washington, DC: American Society for Microbiology.

Mladenovska, Z., Mathrani, I. M. \& Ahring, B. K. (1995). Isolation and characterization of Caldicellulosiruptor lactoaceticus sp. nov., an extremely thermophilic, cellulolytic, anaerobic bacterium. Arch Microbiol 163, 223-230.

Nielsen, P., Mathrani, I. M. \& Ahring, B. K. (1993). Thermoanaerobium acetigenum spec. nov., a new anaerobic, extremely thermophilic, xylanolytic non-spore forming bacterium isolated from an Icelandic hot spring. Arch Microbiol 159, 460-464.

Nielsen, P., Mathrani, I. M. \& Ahring, B. K. (1994). Thermoanaerobium acetigenum sp. nov. In Validation of the Publication of New Names and New Combinations Previously Effectively Published Outside the IJSB, List no. 49. Int J Syst Bacteriol 44, 370-371. 
Rainey, F. A., Donnison, A. M., Janssen, P. H., Saul, D., Rodrigo, A., Bergquist, P. L., Daniel, R. M., Stackebrandt, E. \& Morgan, H. W. (1994). Description of Caldicellulosiruptor saccharolyticus gen. nov., sp. nov.: an obligately anaerobic, extremely thermophilic, cellulolytic bacterium. FEMS Microbiol Lett 120, 263-266.

Rainey, F. A., Donnison, A. M., Janssen, P. H., Saul, D., Rodrigo, A., Bergquist, P. L., Daniel, R. M., Stackebrandt, E. \& Morgan, H. W. (1995). Caldicellulosiruptor gen. nov. In Validation of the Publication of New Names and New Combinations Previously Effectively Published Outside the IJSB, List no. 52. Int J Syst Bacteriol 45, 197-198.

Rainey, F. A., Ward-Rainey, N. L., Janssen, P. H., Hippe, H. \& Stackebrandt, E. (1996). Clostridium paradoxum DSM $7308^{\mathrm{T}}$ contains multiple 16S rRNA genes with heterogeneous intervening sequences. Microbiology 142, 2087-2095.

Saitou, N. \& Nei, M. (1987). The neighbor-joining method: a new method for reconstructing phylogenetic trees. Mol Biol Evol 4, 406-425.

Sissons, C. H., Sharrock, K. R., Daniel, R. M. \& Morgan, H. W. (1987). Isolation of cellulolytic anaerobic extreme thermophiles from New Zealand thermal sites. Appl Environ Microbiol 53, 832-838.

Thompson, J. D., Gibson, T. J., Plewniak, F., Jeanmougin, F. \& Higgins, D. G. (1997). The CLUSTAL_X windows interface: flexible strategies for multiple sequence alignment aided by quality analysis tools. Nucleic Acids Res 25, 4876-4882.

Wayne, L. G., Brenner, D. J., Colwell, R. R. \& 9 other authors (1987). Report of the ad hoc committee on reconciliation of approaches to bacterial systematics. Int J Syst Bacteriol 37, 463-464.

Wiegel, J. (1981). Distinction between the Gram reaction and the Gram type of bacteria. Int J Syst Bacteriol 31, 88.

Wiegel, J. \& Ljungdahl, L. G. (1981). Thermoanaerobacter ethanolicus gen. nov., spec. nov., a new, extreme thermophilic, anaerobic bacterium. Arch Microbiol 128, 343-348.

Zeikus, J. G., Hegge, P. W. \& Anderson, M. A. (1979). Thermoanaerobium brockii gen. nov. and sp. nov., a new chemoorganotrophic, caldoactive, anaerobic bacterium. Arch Microbiol 122, $41-48$. 